\title{
Sever's disease: a common cause of paediatric heel pain
}

\author{
Shabbir Hussain, ${ }^{1}$ Kosar Hussain, ${ }^{2}$ Sahar Hussain, ${ }^{3}$ Sara Hussain ${ }^{4}$
}

1 Department of Paediatrics, Iranian Hospital, Dubai, United Arab Emirates 2Department of Internal Medicine, Rashid Hospital, Dubai Health Authority, Dubai, United Arab Emirates ${ }^{3}$ Department of Pharmacology, College of Medicine and Health Sciences, UAE University, Al Ain, United Arab Emirates

${ }^{4}$ Dubai Medical College, Dubai, United Arab Emirates

\section{Correspondence to} Dr Shabbir Hussain, dr.shabbirhussain@hotmail. com
To cite: Hussain $S$, Hussain K, Hussain S, et al. BMJ Case Rep Published online: [please include Day Month Year] doi:10.1136/ bcr-2013-009758

\section{DESCRIPTION}

A 10 -year-old boy presented with a 5 day history of refusal to walk due to severe bilateral heel pain, which increased with activity. The patient's family correlated the onset of pain to a preceding jumping activity by the child. There was no preceding history of rash, fever, respiratory tract or gastrointestinal tract symptoms. Examination revealed a well-nourished boy with normal vital signs. Foot examination revealed severe tenderness of lateral and posterior aspect of heel bilaterally. Other joint and systemic examination was normal. Laboratory tests showed white cell count $5 \times 10^{3} / \mu$ l, haemoglobin $13.5 \mathrm{~g} / \mathrm{dl}$, platelet $215 \times 10^{3} / \mu \mathrm{l}$, erythrocyte sedimentation rate $34 \mathrm{~mm}, C$ reactive protein $4.97 \mathrm{mg} / \mathrm{dl}$ and blood culture was negative. Rheumatoid factor, antinuclear antibody and antistreptolysin O (ASO) titre levels were negative. Urine analysis, renal function, calcium level and chest $\mathrm{x}$-ray were normal. Heel $\mathrm{x}$-ray showed increased radiodensity of calaneal epiphysis with fragmentation on both sides (figure 1). MRI showed abnormal signal intensity of posterior calcaneal epiphysis and adjacent soft tissue (figure 2). $\mathrm{He}$ was given a course of oral and topical antiinflammatory medication.

Sever disease (calcaneal apophysitis) is the most common aetiology of heel pain in growing children. It is postulated to be caused by repetitive microtrauma due to increased traction by Achilles tendon on its insertion site. ${ }^{1}$ Bilateral involvement

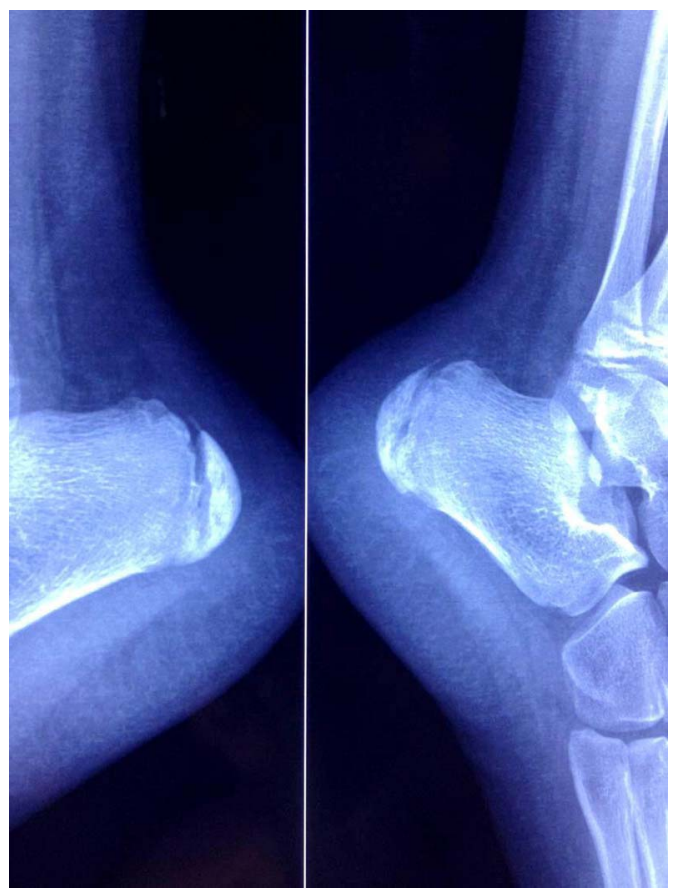

Figure 1 Heel x-ray showed increased radiodensity of calaneal epiphysis on both sides.

is present in approximately $60 \%$ of cases. ${ }^{2}$ Plain $\mathrm{x}$-ray of the heels would demonstrate sclerotic changes and fragmentation; however, this is usually

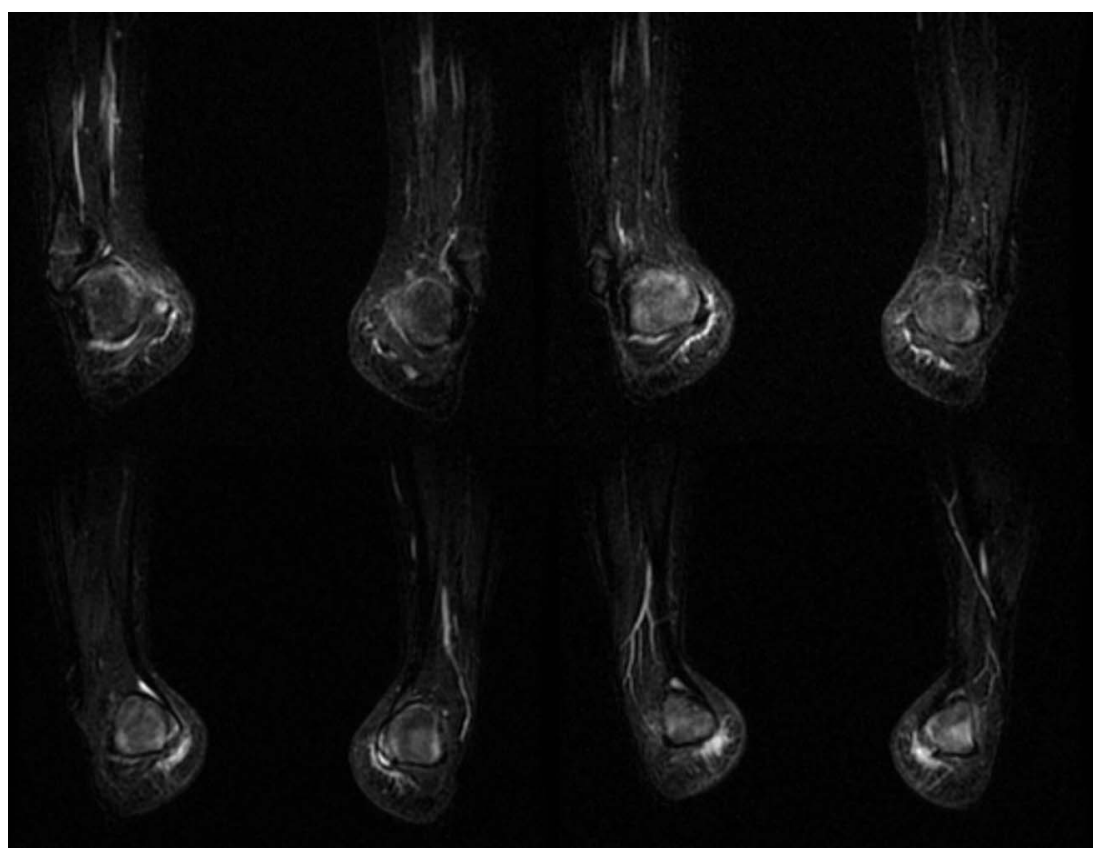

Figure 2 MRI showed abnormal signal intensity of posterior calcaneal epiphysis and adjacent soft tissue. 
difficult to distinguish from normal anatomic variation. MRI showed signal changes in posterior calcaneal epiphysis. Such cases are usually managed conservatively with anti-inflammatory medications and temporary cessation of physical activity.

\section{Learning points}

- Sever disease is the most common cause of heel pain in growing children.

- Bilateral calcaneal apophysitis may be seen.

- It is usually managed conservatively with anti-inflammatory medications and restriction of physical activity.
Competing interests None.

Patient consent Obtained.

Provenance and peer review Not commissioned; externally peer reviewed

\section{REFERENCES}

1 Chiodo WA, Cook KD. Pediatric heel pain. Clin Podiatr Med Surg 2010;27:355-67.

2 Micheli LJ, Ireland ML. Prevention and management of calcaneal apophysitis in children: an overuse syndrome. J Pediatr Orthop 1987;7:34-8.

Copyright 2013 BMJ Publishing Group. All rights reserved. For permission to reuse any of this content visit http://group.bmj.com/group/rights-licensing/permissions.

BMJ Case Report Fellows may re-use this article for personal use and teaching without any further permission.

Become a Fellow of BMJ Case Reports today and you can:

- Submit as many cases as you like

- Enjoy fast sympathetic peer review and rapid publication of accepted articles

- Access all the published articles

- Re-use any of the published material for personal use and teaching without further permission

For information on Institutional Fellowships contact consortiasales@bmjgroup.com

Visit casereports.bmj.com for more articles like this and to become a Fellow 